\title{
The comparison of apoptosis-related protein expressions in neurotoxin-based in vitro Parkinson's Disease models
}

\author{
Gizem KAFTAN 1 (D), Taner DAĞCI 2 (D), Güliz ARMAGAN 1 * id \\ 1 Department of Biochemistry, Faculty of Pharmacy, Ege University, 35100, Bornova, İzmir, Turkey. \\ 2 Department of Physiology, Faculty of Medicine, Ege University, 35100, Bornova, İzmir, Turkey. \\ * Corresponding Author. E-mail: guliz.armagan@ege.edu.tr (G.A.); Tel. +90 5323830693.
}

Received: 02 August 2019 / Accepted: 26 October 2019

\begin{abstract}
Programmed cell death (apoptosis) is mainly responsible for neuronal damage in neurodegenerative diseases. Thus, inhibition of apoptosis could represent an effective strategy in the prevention of these diseases. In this study, we aimed to compare the apoptotic responses of neurotoxins that are widely used to induce neuronal damage in cell culture studies and help to decide the most suitable experimental model for drug studies that target apoptosis. Cell viability analyses were performed by MTT assay following 1-methyl-4-phenylpyridinium (MPP+), 6-hydroxydopamine (6-OHDA), rotenone and paraquat treatments at three different time points (12, 24, 48h). Pro-apoptotic (Bax, Bad, Bak), anti-apoptotic (Bcl-2, Bcl-xl) protein levels and total caspase-3 protein levels were determined by Western Blotting technique following treatments. As expected, all neurotoxins managed to trigger cell death and apoptotic pathway. On the other hand, each neurotoxin was found to enhance and/or reduce the levels of different proteins that are associated with apoptosis. Due to different responses of apoptosis related proteins to neurotoxins, it can be concluded that the determination of target proteins with a number of protein-binding assays prior to cell culture studies and then deciding an in vitro model are essential while screening newly synthesized drugs that target apoptosis.
\end{abstract}

KEYWORDS: Parkinson's disease; neurotoxin; apoptosis; Bax/Bcl-2 ratio.

\section{INTRODUCTION}

Parkinson's disease (PD) is one of the most common neurodegenerative disorder affecting $2 \%$ of the population over 65 years of age [1]. There are various mechanisms including free radical formation, oxidative/nitrosative stress, mitochondrial dysfunction, excitotoxicity, environmental and genetic factors that cause neurodegeneration. These factors lead to neuronal dysfunction, atrophy and finally apoptosis [2]. It is not easy to find an effective therapeutic approach for neurodegenerative diseases because of the complexity of processes. Nowadays, new potential drugs such as GSK3 $\beta$ inhibitors, cyclin dependent kinase inhibitors, c-JNK pathway inhibitors and apoptosis inhibitors are under investigation for clinical applications in the future [3-7].

Apoptosis is a controlled and programmed cell death responsible for regulating homeostasis of multicellular organisms under physiological conditions [8-11]. Apoptosis occurs via the intrinsic (mitochondrial) pathway, extrinsic (death receptor) pathway and endoplasmic reticulum (ER) pathway [12]. The mitochondrial pathway is mainly regulated by Bcl-2 (B-cell lymphoma 2) family proteins which consist of three sub-families namely anti-apoptotic sub-family (Bcl-xL (B-cell lymphoma-extra large) and Bcl-2), proapoptotic BH3 only proteins (Bid (BH3 interacting-domain death agonist) and Bad (Bcl-2 associated death promoter)) and sub-family including Bak (Bcl-2 homologous antagonist killer) and Bax (Bcl-2 associated $\mathrm{x}$ protein) [13].

Environmental factors have been shown to contribute to the incidence of Parkinson's disease. Pesticides such as insecticide, herbicide, rodenticide, fungicide, fumigant exhibit a wide variety of chemical structures [14]. 1-methyl-4-phenyl-1,2,3,6-tetrahydropyridine (MPTP) is the first known agent which induces Parkinsonian symptoms in animal models [15]. MPTP can cross the blood-brain barrier and converted into its toxic oxidized product, 1-methyl-4-phenylpyrdinium $\left(\mathrm{MPP}^{+}\right)$, inside the brain cells [16]. Paraquat $\left(1,1^{1}-\right.$ dimethyl-4,4'-bipyridinium dichloride) is a highly toxic quaternary nitrogenous herbicide. After absorption, paraquat accumulates in the lungs and kidneys and triggers acute toxicological effects regardless of the route

How to cite this article: Kaftan G, Dağcl T, Armağan G. The comparison of apoptosis-related protein expressions in neurotoxin-based in vitro Parkinson's Disease models. J Res Pharm. 2020; 24(1): 112-120. 
of exposure. In contrast to $\mathrm{MPP}^{+}$, paraquat has been reported to be a weak inhibitor of complex I of the electron transport chain [17]. Rotenone is a broad-spectrum agricultural pesticide and a high-affinity specific complex I (NADH-dehydrogenase) inhibitor. It is highly hydrophobic and easily passes through biological membranes. Unlike MPTP, rotenone does not require a dopamine transporter (DAT) to reach the cytoplasm [17]. 6-hydroxydopamine (6-OHDA) is an other neurotoxin commonly used in animal models of PD increases the iron levels in the substantia nigra $[18,19]$ and interacts directly with the complexes I and IV of the mitochondrial respiratory chain, leading to respiratory inhibition and oxidative stress [20].

Very few studies were reported to compare the biological and toxicological responses of neural and glial cells following widely used experimental toxins [21-25]. In this study, we aimed to compare four different neurotoxins in terms of apoptotic/anti-apoptotic protein alterations while triggering dopaminergic cell death. Our results may help to choose suitable experimental model while studying drug candidate molecules that target specific apoptosis-related proteins.

\section{RESULTS}

\subsection{Neurotoxin treatments decreased survival and viability of cells}

Selected neurotoxins (MPP+, rotenone, paraquat and 6-OHDA) are widely used toxins for inducing dopaminergic cell damage in in vitro studies. In this study, to confirm their toxicity, the cells were treated with $\mathrm{MPP}^{+}$, rotenone, paraquat and 6-OHDA individually at three different concentrations and three different time periods (12, 24, 48 hours). As shown in Figure 1, IC50 values for MPP+, rotenone, paraquat and 6-OHDA were found as $2.3 \mathrm{mM}, 44.37 \mu \mathrm{M}, 388.4 \mu \mathrm{M}$ and $79.1 \mu \mathrm{M}$, respectively at $24 \mathrm{~h}$.

A
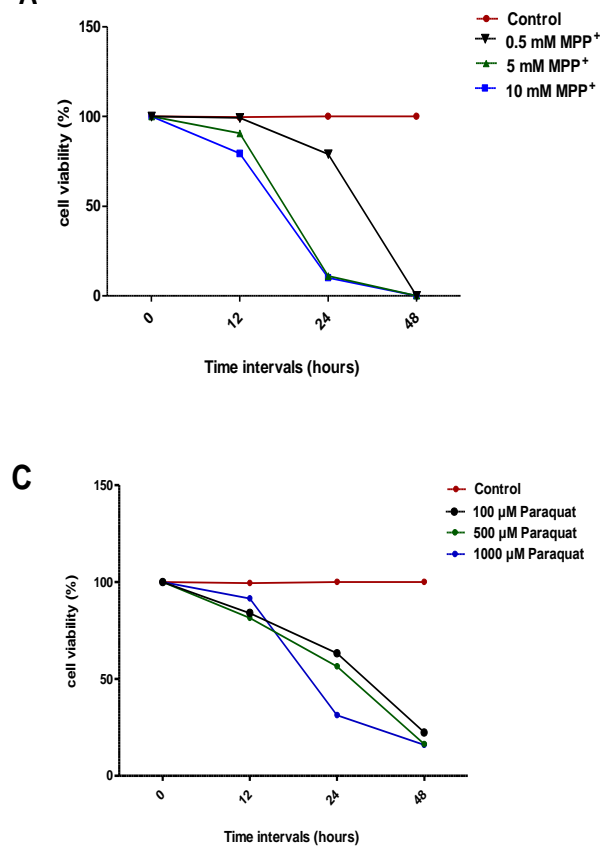

B

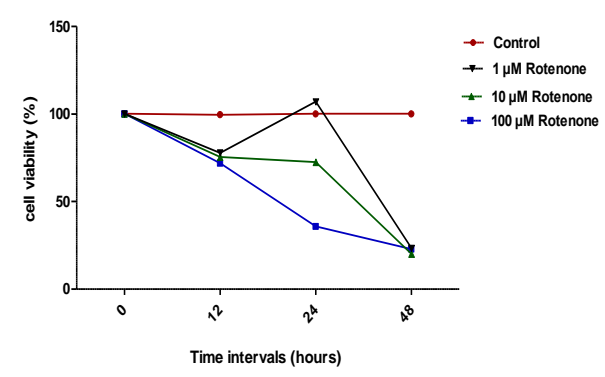

D

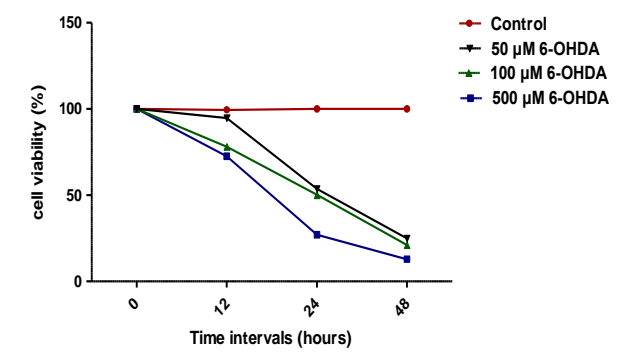

Figure 1. Effect of MPP+ (A), rotenone (B), paraquat (C) and 6-OHDA (D) on cell viability at different concentrations and time points.

\subsection{Effect of $\mathrm{MPP}^{+}$, rotenone, paraquat, 6-OHDA on pro-apoptotic and anti-apoptotic protein levels}

To evaluate the role of neurotoxins and compare their efficiencies, the effects of neurotoxins on expressions of pro-apoptotic (Bax, Bak and Bad) and anti-apoptotic (Bcl-2, Bcl-xl) proteins were determined. As expected, pro-apoptotic and anti-apoptotic protein levels altered following treatments.

As shown in Figure 2, Bax protein levels were significantly increased following rotenone and paraquat treatments when compared to other groups $(\mathrm{p}<0.05)$. Among neurotoxins, rotenone was found to increase Bax levels at highest ratio at selected concentration $(1,69$-fold, $\mathrm{p}<0.0001)$. Similarly, Bak protein levels were 
significantly increased (1.04-fold) following paraquat ( $p<0.05)$. As it is shown in Fig. 2, Bad protein levels were significantly increased when cells were treated by 6-OHDA $(2.67$-fold, $\mathrm{p}<0.05)$.

A
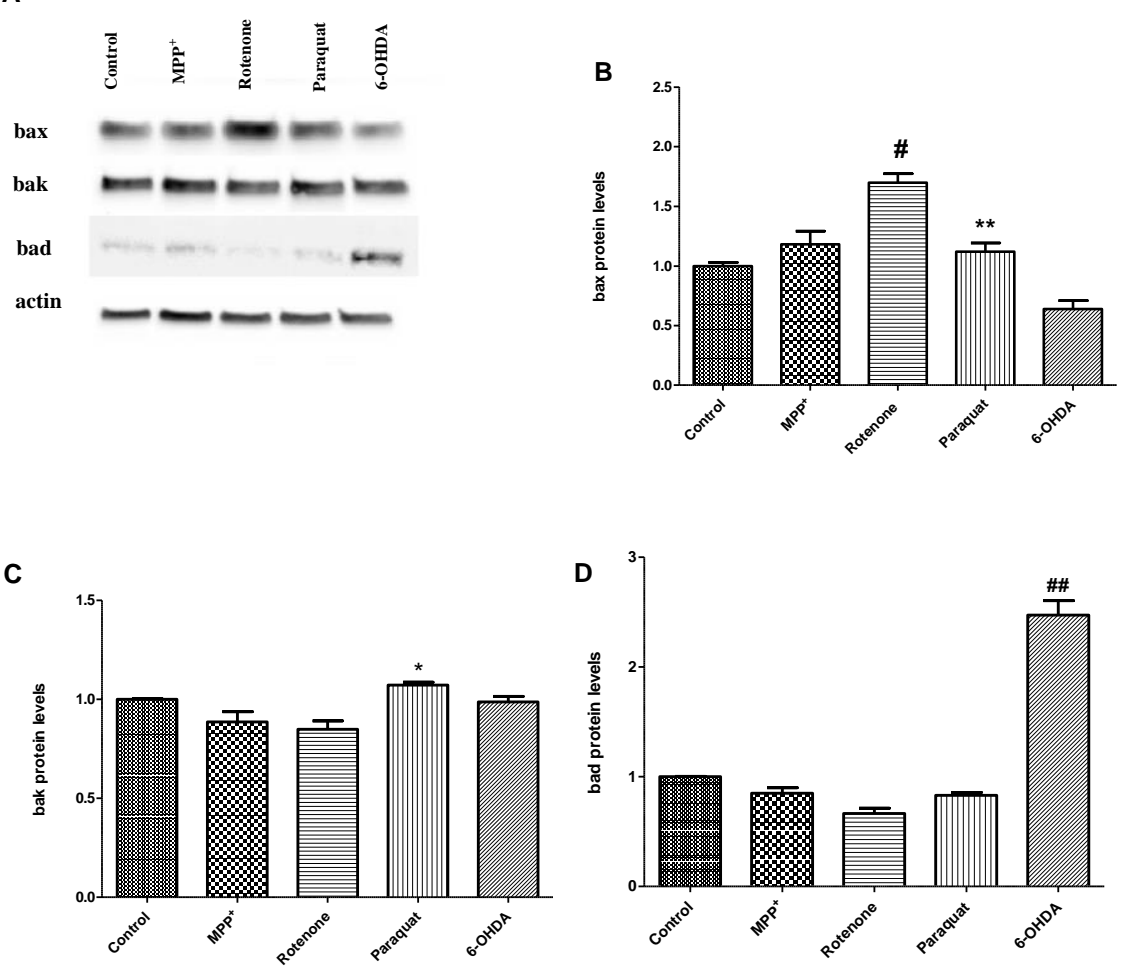

Figure 2. Changes in Bax, Bak and Bad levels following MPP+ $(2 \mathrm{mM})$, rotenone $(50 \mu \mathrm{M})$, paraquat $(500$ $\mu \mathrm{M})$ and 6 -OHDA $(100 \mu \mathrm{M})$ at $24 \mathrm{~h}$. \#p $<0.0001$ vs. all groups; ${ }^{*} \mathrm{p}<0.05$ vs. other neurotoxin groups; ${ }^{* *} \mathrm{p}$ $<0.05$ vs. untreated and 6-OHDA-treated cells.

Figure 3 showed the effect of four neurotoxins on anti-apoptotic Bcl-2 and Bcl-xl protein levels in cells. $\mathrm{MPP}^{+}$, rotenone and paraquat treatments significantly decreased Bcl-2 and Bcl-xl levels when compared to untreated cells ( $\mathrm{p}<0.05)$. 1.17, 1.08, 1.12, 0.96- fold decreases in Bcl-2 levels were observed following MPP+, rotenone and paraquat treatments, respectively. In addition to these neurotoxins, 6-OHDA treatment significantly decreased Bcl-xl levels as well (6.25-fold).

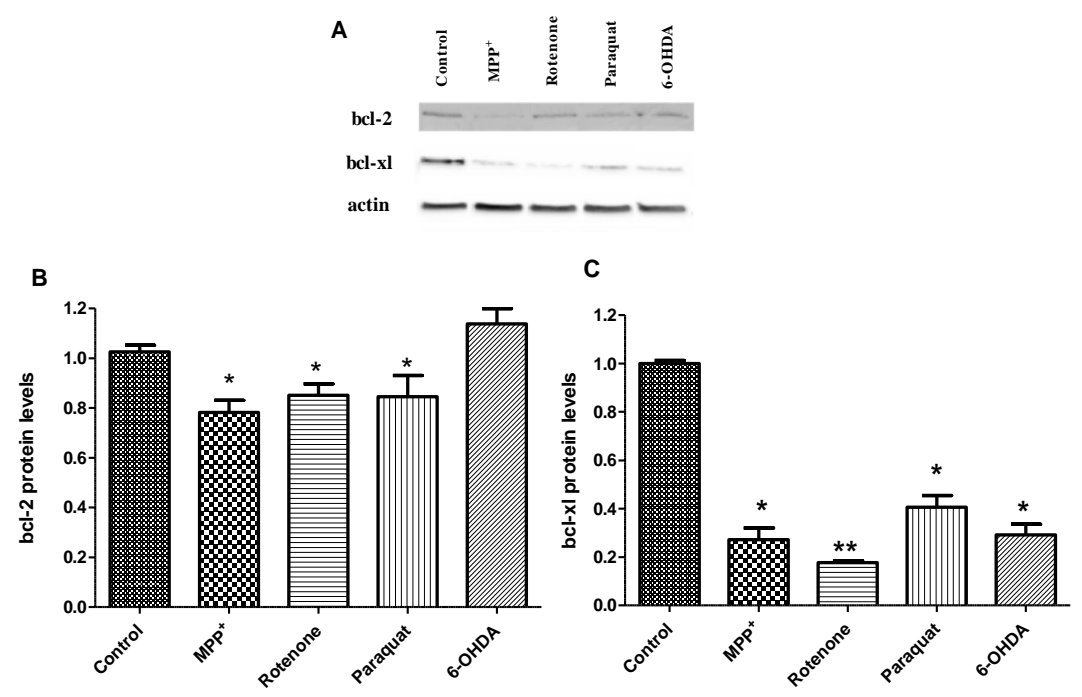

Figure 3. Changes in Bcl-2 and Bcl-xl levels following MPP+ $(2 \mathrm{mM})$, rotenone $(50 \mu \mathrm{M})$, paraquat $(500 \mu \mathrm{M})$ and 6-OHDA $(100 \mu \mathrm{M})$ at $24 \mathrm{~h} .{ }^{*} \mathrm{p}<0.05$ vs. untreated cells; ${ }^{* *} \mathrm{p}<0.001 \mathrm{vs}$. all groups. 
In this study, we assessed the effect of neurotoxins in the relative ratio of Bax/Bcl-2 proteins by Western Blot analysis. Meanwhile, selected neurotoxins were compared in terms of Bax/Bcl-2 ratio. As shown in Figure 4, the densitometric analysis demonstrated that $\mathrm{MPP}^{+}$, rotenone and paraquat-treated cells had high Bax/Bcl-2 ratio as compared with untreated and 6-OHDA-treated cells $(\mathrm{p}<0.05)$. When neurotoxins were compared, rotenone was found to increase Bax/Bcl-2 ratio more efficiently (1.83-fold, $\mathrm{p}<0.05)$.

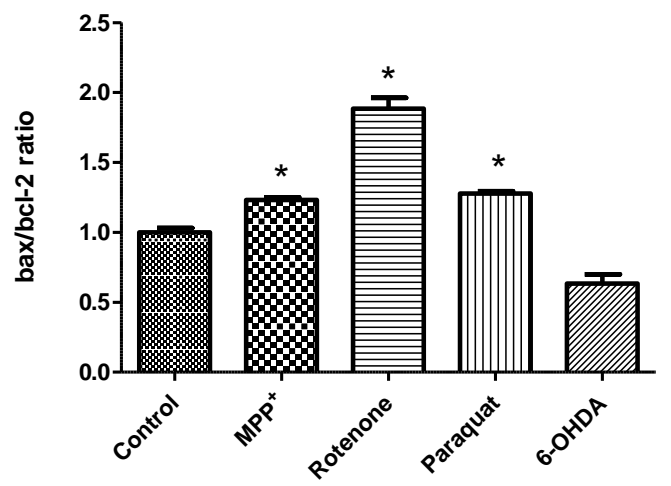

Figure 4. Changes in Bax/Bcl-2 ratio following $\mathrm{MPP}^{+}(2 \mathrm{mM})$, rotenone $(50 \mu \mathrm{M})$, paraquat $(500 \mu \mathrm{M})$ and 6OHDA $(100 \mu \mathrm{M})$ at $24 \mathrm{~h} .{ }^{*} \mathrm{p}<0.05$ vs. untreated cells.

\subsection{Effect of $\mathrm{MPP}^{+}$, rotenone, paraquat, 6-OHDA on caspase-3 protein levels}

The alterations in caspase- 3 protein levels following the administration of four neurotoxins in SHSY5Y cells were evaluated (Figure 5). Although insignificant, both $\mathrm{MPP}^{+}$and 6-OHDA decreased total caspase- 3 levels at $24 \mathrm{~h}$ exposure $(\mathrm{p}>0.05)$. On the other hand, other neurotoxins did not change caspase-3 levels.
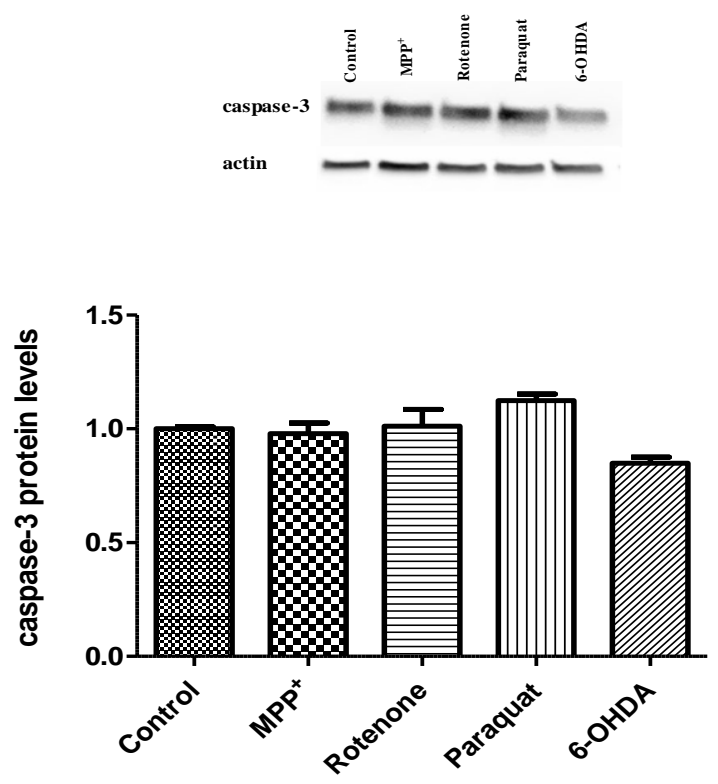

Figure 5. Effect of $\mathrm{MPP}^{+}(2 \mathrm{mM})$, rotenone $(50 \mu \mathrm{M})$, paraquat $(500 \mu \mathrm{M})$ and 6-OHDA $(100 \mu \mathrm{M})$ on total caspase- 3 protein levels after 24 hours of administration.

\section{DISCUSSION}

The compounds with structural diversity including MPTP (active form $\mathrm{MPP}^{+}$), rotenone, paraquat and 6-OHDA are used to generate the Parkinson's Disease experimental models. In this study, we aimed to compare these four in vitro experimental models in terms of apoptotic responses. At first, cellular viability following different concentrations of neurotoxins at three different time points were evaluated. Similar to 
previous findings, all selected compounds achieved to decrease cell viability nearly $50 \%$ at $24 \mathrm{~h}$ dosedependently. Recent studies showed that $\mathrm{MPP}^{+}$significantly decreased cell viability in a dose-dependent manner [26, 27]. While studying with SH-SY5Y cells, different concentrations suh as $500 \mu \mathrm{M}, 1 \mathrm{mM}$ or $2 \mathrm{mM}$ $\mathrm{MPP}^{+}$were shown to decrease cell viability [27, 28]. In our study model, $2.3 \mathrm{mM}$ concentration of MPP+ was needed to decrease cell viability to $50 \%$ at $24 \mathrm{~h}$.

Previous studies reported that exposure to $\mathrm{nM}$ concentrations of rotenone for 24 hours was found to decrease SH-SY5Y cell viability to 50\% when compared to untreated cells [29, 30]. However, rotenone at higher concentrations were needed to effect cellular viability in our study model, similar to recent studies [31, 32]. At lower concentrations, we could not observe any damage. Thus, $50 \mu \mathrm{M}$ rotenone was used to induce cellular damage for further analysis. Consistent with previous studies, we observed significant decreases in cell viability following paraquat or 6-OHDA treatments at different time points [33-35]. It is suggested that performing dose-response studies while studying, particularly, rotenone-induced neurotoxicity is very important before investigating molecular responses of neurotoxins.

Although it is reported that neurodegenerative diseases have common mechanisms including oxidative stress, protein aggregation, mitochondrial dysfunction and apoptosis etc., the molecular mechanisms that lead to neuronal pathology are still unclear. Therefore, an effective treatment strategy for these diseases is not yet available. Following the discovery of a link between apoptosis and neurodegenerative diseases, there is a widespread interest in agents that inhibiting the apoptosis of neural cells.

Bcl-2 family proteins are divided into two groups as apoptotic and anti-apoptotic proteins that are mainly involved in the regulation of apoptosis [36,37]. Enhanced Bax and Bad activities are very crucial for cellular fate due to the regulatory role of Bax for release of proapoptotic mitochondrial proteins into the cytoplasm. Siddiqui et al. (2013) showed that rotenone exposure significantly increased mRNA and protein levels of Bax and p53 as well as decreased mitochondrial membrane potential supporting its mitochondrialtargeted effect [38]. Similarly, it was reported that Bax levels were significantly increased when cells treated with $150 \mu \mathrm{M}$ 6-OHDA [34]. In our study, the alterations in levels of apoptosis-related proteins were evaluated following neurotoxin treatments. As expected, rotenone and paraquat treatments significantly increased Bax and Bak protein levels in our study. Surprisingly, MPP+ and 6-OHDA at selected concentrations that caused $50 \%$ cell death were failed to increase Bax protein levels $(p>0.05)$. On the other hand, 6-OHDA was the only neurotoxin which managed to increase Bad protein levels. In the light of these findings, it can be suggested that working concentration of a neurotoxin should be carefully chosen and confirmed before further specific analysis on pro-apoptotic proteins.

Bcl-2 and Bcl-xl are anti- apoptotic proteins that inhibit apoptosis by directly binding to pro-apoptotic proteins [39]. In our study, $\mathrm{MPP}^{+}$, rotenone and paraquat treatments significantly decreased Bcl-2 and Bcl-xl protein levels, consistent with previous studies [38, 40]. All neurotoxins were found to exert similar behaviour. Thus, we observed that any neurotoxin is not superior to the other in terms of anti-apoptotic protein regulation. In addition to individual analysis of proteins, the ratio of Bax to Bcl-2 can be used as an indicator of susceptibility of a cell to apoptosis [41]. Since Bax/Bcl-2 ratio is associated with increased cell death, we examined apoptotic stimuli by increased Bax/Bcl-2 ratio following treatments in our study model. $\mathrm{MPP}^{+}$, rotenone and paraquat treatments were found to increase $\mathrm{Bax} / \mathrm{Bcl}-2$ ratio when compared to untreated cells suggesting and confirming their modulatory roles in pore formation on mitochondrial membrane.

Following activation of caspases during apoptosis, there is an increase in cleaved caspase- 3 levels which is the active form of caspase-3 enzyme. Therefore, significant decrease can be observed in total caspase-3 levels. However, neurotoxins could not effect protein expression levels of caspase-3 at selected concentrations and time period of exposure in our study model. In agreement with the earlier findings by Ramachandiran et al. (2007), we did not observe any evidence of caspase-dependent apoptosis in cells during any of neurotoxins-induced toxicity. Further studies are still needed to compare the mechanisms of action of various neurotoxins that are used to induce cellular damage [21].

\section{CONCLUSION}

Therapeutic approaches that have been shown to be effective for a variety of neurodegenerative disorders in in vitro and animal models and that target the apoptotic pathway appear to give conflicting results in human clinical trials [6,42]. Similar to previous data obtained by Giordano et al. [43], we did not observe similar changes in terms of apoptotic proteins following rotenone, $\mathrm{MPP}^{+}$, paraquat, 6-OHDA 
treatments at doses that induce cell death in SH-SY5Y cells. In the light of these findings, it can be concluded that deciding an experimental model should be one of the most important strategies before starting drug studies that target apoptosis.

\section{MATERIALS AND METHODS}

\subsection{Cell culture and treatments}

The human neuroblastoma cell line (SH-SY5Y) used in this study was purchased from the American Type Culture Collection (ATCC, Catalog \#CRL-2266). Cells were suspended in complete Dulbecco's modified Eagle Medium (DMEM) (Life Technologies, Gibco BRL, Grand Island, NY) supplemented with $10 \%$ fetal bovine serum (FBS, Hyclone), $1 \%$ penicillin and streptomycin $(100 \mathrm{U} / \mathrm{ml}$, Invitrogen) and plated in poly-L-lysine-coated culture dishes. The cultures were incubated in $1: 4$ passages at $37^{\circ} \mathrm{C}$ in $5 \% \mathrm{CO}_{2} 95 \%$ humidified atmosphere. For drug treatments, cells were transferred to 6- or 96-well plates or culture dish.

\subsection{Parkinsonian toxin- induced toxicity}

The dose-response and time-response studies for $\mathrm{MPP}^{+}$, rotenone, paraquat and 6-OHDA were performed to determine the concentration (IC50) and duration of toxicity. Cells were seeded (5X10 ${ }^{3}$ cells/well) in 96-well culture dishes and incubated for 24 hours in $5 \% \mathrm{CO}_{2}$ and $37^{\circ} \mathrm{C}$ incubator. Various concentrations of toxins $\left(0.5,5,10 \mathrm{mM}\right.$ for $\mathrm{MPP}^{+} ; 0.1,1,10 \mu \mathrm{M}$ for rotenone; $0.1,0.5,1 \mathrm{mM}$ for paraquat; 50 , $100,500 \mu \mathrm{M}$ for 6-OHDA) were added and incubated for 12, 24 or 48 hours. Then, 3-(4,5-dimethylthiazol-2yl)-2,5-diphenyl tetrazolium bromide (MTT) cell viability test was applied. IC50 value and exposure time were calculated for each toxins.

\subsection{MTT assay}

Percent cell viability was assessed using the MTT assay. Following exposures, $20 \mu \mathrm{L}$ of MTT solution (5 $\mathrm{mg} / \mathrm{ml}$ phosphate buffer) was added to each well and incubated for 3 hours in $5 \% \mathrm{CO}_{2}$ and $37^{\circ} \mathrm{C}$ incubator. Then, $100 \mu \mathrm{L}$ DMSO was added and kept in a $5 \% \mathrm{CO} 2$ incubator at $37^{\circ} \mathrm{C}$ for 10 minutes to dissolve the formazan crystals. Microplate reader (Multiskan Go, Thermo Scientific) was used to measured each well at a wavelength of $570 \mathrm{~nm}$.

\subsection{Western blotting}

BCA Protein Assay Kit (Pierce, 23225) was used for protein content determination. Western blotting was performed by loading $30 \mu \mathrm{g}$ protein on $10 \%(\mathrm{w} / \mathrm{v})$ tris-glycine denaturing gels and separating proteins by electrophoresis, then transferring to PVDF membrane. After blocking, the membrane was incubated with primary antibodies (anti-Bax, anti-Bcl-2, anti-Bcl-xl, anti-Bad, anti-Bak, anti-caspase-3; 1:1000, Cell Signaling) at $+4^{\circ} \mathrm{C}$ overnight. After washing, the membrane was incubated with peroxidase-conjugated secondary antibodies for $1 \mathrm{~h}$ to visualize labeled proteins by enhanced chemiluminescence.

\subsection{Statistical analysis}

All data were expressed as means \pm standard deviation (SD) for six independent experiments for MTT analyses and three independent experiments for protein expression analyses. Comparisons of means between groups were performed by one-way analysis of variance (ANOVA) followed by Tukey's post hoc test. $\mathrm{p}<0.05$ was considered statistically significant.

Acknowledgements: This work was supported by The Scientific and Technological Research Council of Turkey (TUBITAK-2209-A Programme) under Grant (Project No: 1919B011603194).

Author contributions: Concept - G.A.; Design - G.K., T.D., G.A.; Supervision - T.D., G.A..; Resources - T.D., G.A..; Materials - G.K., G.A.; Data Collection and/or Processing - G.K., T.D., G.A.; Analysis and/or Interpretation - G.K., G.A.; Literature Search - G.K., T.D., G.A.; Writing - G.K., T.D., G.A.; Critical Reviews - G.K., T.D., G.A.

Conflict of interest statement: The authors report no conflict of interest. 


\section{REFERENCES}

[1] Dauer W, Przedborski S. Parkinson's Disease: mechanisms and models. Neuron. 2003; 39(6): 889-909. [CrossRef]

[2] Yuan H, Zhang ZW, Liang LW, Shen Q, Wang XD, Ren SM, Ma HJ, Jiao SJ, Liu P. Treatment strategies for Parkinson's disease. Neurosci Bull. 2010; 26(1): 66-76. [CrossRef]

[3] Lim AC, Qi RZ. Cyclin-dependent kinases in neural development and degeneration. J Alzheimers Dis. 2003; 5(4): 329-335. [CrossRef]

[4] Selenica ML, Jensen HS, Larsen AK, Pedersen ML, Helboe L, Leist M, and Lotharius J. Efficacy of small molecule glycogen synthase kinase-3 inhibitors in the postnatal rat model of tau hyperphosphorylation. Br J Pharmacol. 2007; 152(6): 959-979. [CrossRef]

[5] Lee HG, Casadesus G, Zhu X, Castellani RJ, McShea A, Perry G, Petersen RB, Bajic V, Smith MA. Cell cycle re-entry mediated neurodegeneration and its treatment role in the pathogenesis of Alzheimer's disease. Neurochem Int. 2009; 54(2): 84-88. [CrossRef]

[6] Fan Z, Wang X, Zhang M, Zhao C, Mei C, Li P. MAPK pathway inhibitors attenuated hydrogen peroxide induced damage in neural cells. Biomed Res Int. 2019; 5962014. [CrossRef]

[7] Armagan G, Sevgili E, Gürkan FT, Köse FA, Bilgiç T, Dagcı T, Saso L. Regulation of the Nrf2 pathway by glycogen synthase kinase-3 $\beta$ in MPP+-induced cell damage. Molecules. 2019; 24: 1377. [CrossRef]

[8] Kroemer G, Galluzzi L, Vandenabeele P, Abrams J, Alnemri ES, Baehrecke EH, Blagosklonny MV, El-Deiry WS, Golstein P, Green DR, Hengartner M, Knight RA, Kumar S, Lipton SA, Malorni W, Nuñez G, Peter ME, Tschopp J, Yuan J, Piacentini M, Zhivotovsky B, Melino G. Classification of cell death: Recommendations of the Nomenclature Committee on Cell Death. Cell Death. 2009; 16(1): 3-11. [CrossRef]

[9] Galluzzi L, Maiuri MC, Vitale I, Zischka H, Castedo M, Zitvogel L, Kroemer G. Cell death modalities: classification and pathophysiological implications. Cell Death Differ. 2007; 14(7): 1237-1243. [CrossRef]

[10] Tait SW, Green DR. Mitochondria and cell death: outer membrane permeabilization and beyond. Nat Rev Mol Cell Biol. 2010; 11(9): 621-632. [CrossRef]

[11] Czabotar PE, Lessene G, Strasser A, Adams JM. Control of apoptosis by the BCL-2 protein family: implications for physiology and therapy. Nat Rev Mol Cell Biol. 2014; 15(1): 49-63. [CrossRef]

[12] Hong JS, Kim NH, Choi CY, Lee JS, Na D, Chun T Lee YS. Changes in cellular microRNA expression induced by porcine circovirus type 2-encoded proteins. Vet Res. 2015; 46(1): 39-53. [CrossRef]

[13] Cory S, Adams JM. The Bcl2 family: regulators of the cellular life-or-death switch. Nat Rev Cancer. 2002; 2(9): 647656. [CrossRef]

[14] Hatcher JM, Pennell KD, Miller GW. Parkinson's disease and pesticides: a toxicological perspective. Trends Pharmacol Sci. 2008; 29(6): 322-329. [CrossRef]

[15] Nandipati S, Litvan I. Environmental exposures and Parkinson's Disease. Int J Environ Res Public Health. 2016; 13: 881. [CrossRef]

[16] Brown TP, Rumsby PC, Capleton AC, Rushton L, Levy LS. Pesticides and Parkinson's Disease-Is There a Link? Environ Health Perspect. 2006; 114(2): 156-164. [CrossRef]

[17] Franco R, Li S, Rodriguez-Rocha H, Burns M, Panayiotidis MI. Molecular mechanisms of pesticide-induced neurotoxicity: Relevance to Parkinson's Disease. Chem Biol Interact. 2010; 188(2): 289-300. [CrossRef]

[18] Oestreicher E, Sengstock GJ, Riederer P, Olanow CW, Dunn AJ, Arendash GW. Degeneration of nigrostriatal dopaminergic neurons increases iron within the substantia nigra: a histochemical and neurochemical study. Brain Res. 1994; 660(1): 8-18. [CrossRef]

[19] Le W, Sayana P, Jankovic J. Animal models of Parkinson's Disease: A gateway to therapeutics? Neurotherapeutics 2014; 11(1): 92-110. [CrossRef]

[20] Kunikowska G, Jenner P. 6-Hydroxydopamine-lesioning of the nigrostriatal pathway in rats alters basal ganglia mRNA for copper, zinc- and manganese-superoxide dismutase, but not glutathione peroxidase. Brain Res. 2001; 922(1): 51-64. [CrossRef]

[21] Ramachandiran S, Hansen JM, Jones DP, Richardson JR, Miller GW. Divergent mechanisms of paraquat, MPP+, and rotenone toxicity: oxidation of thioredoxin and caspase-3 activation. Toxicol Sci. 2007; 95(1): 163-171. [CrossRef] 
[22] Choi WS, Kruse SE, Palmiter RD, Xia Z. Mitochondrial complex I inhibition is not required for dopaminergic neuron death induced by rotenone, MPP+, or paraquat. Proc Natl Acad Sci U S A. 2008; 105(39): 15136-15141. [CrossRef]

[23] Garcia-Garcia A, Anandhan A, Burns M, Chen H, Zhou Y, Franco R. Impairment of Atg5-dependent autophagic flux promotes paraquat- and $\mathrm{MPP}^{+}$-induced apoptosis but not rotenone or 6-hydroxydopamine toxicity. Toxicol Sci. 2013; 136(1): 166-182. [CrossRef]

[24] Martins JB, Bastos Mde L, Carvalho F, Capela JP. Differential effects of methyl-4-phenylpyridinium ion, rotenone, and paraquat on differentiated SH-SY5Y Cells. J Toxicol. 2013; 2013: 347312. [CrossRef]

[25] Rabaneda-Lombarte N, Xicoy-Espaulella E, Serratosa J, Saura J, Solà C. Parkinsonian neurotoxins impair the proinflammatory response of glial cells. Front Mol Neurosci. 2019; 11: 479. [CrossRef]

[26] Kim IS, Ganesan P, Choi DK. Cx43 mediates resistance against MPP+-induced apoptosis in SH-SY5Y neuroblastoma cells via modulating the mitochondrial apoptosis pathway. Int J Mol Sci. 2016; 17: $1819-1830$. [CrossRef]

[27] Zhong J, Yu H, Huang C, Zhong Q, Chen Y, Xie J, Zhou Z, Xu J, Wang H. Inhibition of phosphodiesterase 4 by FCPR16 protects SH-SY5Y cells against MPP+-induced decline of mitochondrial membrane potential and oxidative stress. Redox Biology. 2018; 16: 47-58. [CrossRef]

[28] Jouha J, Loubidi M, Bouali J, Hamri S, Hafid A, Suzenet F, Guillaumet G, Dagcı T, Khouili M, Aydın F, Saso L, Armagan G. Synthesis of new heterocyclic compounds based on pyrazolopyridine scaffold and evaluation of their neuroprotective potential in MPP+-induced neurodegeneration. Eur J Med Chem. 2017; 129: 41-52. [CrossRef]

[29] Newhouse K, Hsuan SH, Chang SH, Cai B, Wang Y, Xia Z. Rotenone-induced apoptosis is mediated by p38 and JNK MAP kinases in human dopaminergic SH-SY5Y cells. Toxicol Sci. 2004; 79(1): 137-146. [CrossRef]

[30] Nataraj J, ManivasagamT, Justin Thenmozhi A, Essa MM. Neuroprotective effect of asiatic acid on rotenoneinduced mitochondrial dysfunction and oxidative stress-mediated apoptosis in differentiated SH-SYS5Y cells. Nutr Neurosci. 2017; 20(6): 351-359. [CrossRef]

[31] Nisar R, Hanson PS, He L, Taylor RW, Blain PG, Morris CM. Diquat causes caspase-independent cell death in SHSY5Y cells by production of ROS independently of mitochondria. Arch Toxicol. 2015; 89(10): 1811-1825. [CrossRef]

[32] Wu HC, Hu QL, Zhang SJ, Wang YM, Jin ZK, Lv LF, Zhang S, Liu ZL, Wu HL, Cheng OM. Neuroprotective effects of genistein on SH-SY5Y cells overexpressing A53T mutant a-synuclein. Neural Regen Res. 2018; 13(8): $1375-1383$. [CrossRef]

[33] Huang CL, Lee YC, Yang YC, Kuo TY, Huang NK. Minocycline prevents paraquat-induced cell death through attenuating endoplasmic reticulum stress and mitochondrial dysfunction. Toxicol Lett. 2012; 209(3): $203-210$. [CrossRef]

[34] Esmaeili-Mahani S, Vazifekhah S, Pasban-Aliabadi H, Abbasnejad M, Sheibani V. Protective effect of orexin-A on 6hydroxydopamine-induced neurotoxicity in SH-SY5Y human dopaminergic neuroblastoma cells. Neurochem Int. 2013; 63(8): 719-725. [CrossRef]

[35] Yamada A, Aki T, Unuma K, Funakoshi T, Uemura K. Paraquat induces epithelial-mesenchymal transition-like cellular response resulting in fibrogenesis and the prevention of apoptosis in human pulmonary epithelial cells. PLoS One. 2015; 10(3): e0120192. [CrossRef]

[36] Burke RE. Programmed cell death and new discoveries in the genetics of parkinsonism. J Neurochem. 2008; 104(4): 875-890. [CrossRef]

[37] Venderova K, Park DS. Programmed cell death in Parkinson's Disease. Cold Spring Harb Perspect Med. 2012; 2(8). [CrossRef]

[38] Siddiqui MA, Ahmad J, Farshori NN, Saquib Q, Jahan S, Kashyap MP, Ahamed M, Musarrat J, Al-Khedhairy AA. Rotenone-induced oxidative stress and apoptosis in human liver HepG2 cells. Mol Cell Biochem. 2013; 384(1-2): 5969. [CrossRef]

[39] Anvekar RA, Asciolla JJ, Missert DJ, Chipuk JE. Born to be alive: a role for the BCL-2 family in melanoma tumor cell survival, apoptosis, and treatment. Front Oncol. 2011; 1(34). [CrossRef]

[40] Hathaichotia S, Visitnonthachaia D, Ngamsiria P, Niyomchanc A, Tsogtbayara O, Wisessaowapaka C, Watcharasit $\mathrm{P}$, Satayavivad J. Paraquat induces extrinsic pathway of apoptosis in A549 cells by induction of DR5 and repression of anti-apoptotic proteins, DDX3 and GSK3 expression. Toxicol In Vitro. 2017; 42: 123-129. [CrossRef] 
[41] Oltval Z, Milliman CL, Korsmeyer SJ. Bcl-2 heterodimerizes in vivo with a conversed homolog, Bax, that accelerates programmed cell death. Cell. 1993; 74(4): 609-619. [CrossRef]

[42] Waldmeier P, Bozyczko-Coyne D, Williams M, Vaught JL. Recent clinical failures in Parkinson's disease with apoptosis inhibitors underline the need for a paradigm shift in drug discovery for neurodegenerative diseases. Biochem Pharmacol. 2006; 72(10): 1197-1206. [CrossRef]

[43] Giordano S, Lee J, Darley-Usmar VM, Zhang J. Distinct effects of rotenone, 1-methyl-4-phenylpyridinium and 6hydroxydopamine on cellular bioenergetics and cell death. PLoS One. 2012; 7(9): e44610. [CrossRef]

This is an open access article which is publicly available on our journal's website under Institutional Repository at http://dspace.marmara.edu.tr. 